\title{
Peatland water conservation by agroforestry system
}

\author{
Yuli Lestari $^{1}$ and Mukhlis ${ }^{1}$ \\ ${ }^{1}$ Indonesian Swampland Agricultural Research Institute (ISARI), Banjarbaru South Kalimantan
}

\begin{abstract}
Peat swamp forest have a high economic value and are potential for agricultural development. However, peatlad are fragile ecosystems because they are easily damaged and difficult to restore. The main problem of all peat soil types is their irreversible drying. In this condition the peat soil is easy burning, unable to store water, and if the groundwater is far from the surface, the plants will be stressed from lack of water. Therefore to support sustainable agricultural development on peatlands it requires careful planning, application of appropriate technology and suitable management. One of the land management systems that can be applied on peatlands is combining agricultural crop and forest plant (agroforestry). Forest plant and seasonal agriculture crops can increase $\mathrm{CO} 2$ absorption so that photosynthetic efficiency and oxygen production increase. These proses increase the production of biomass which can maintain soil organic matter and prevent erosion. Organic matter enhance the effectiveness of rewetting and water retention capacity. In addition, this system also affects the microclimate, such as the soil becoming more humid because it gets shade from the vegetation above it, so reduce temperature and elevated air moisture. Indirectly, agroforestry can reduce excessive evaporation and maintains the ground water level, especially during the dry season. This review aim to explain the role of intercropping system in peatland water conservation.
\end{abstract}

Keywords: Sustainable agriculture, intercropping, water retention capacity

\section{Introduction}

Peatlands are wetlands that are formed from piles of organic matter which are plant debris, whether decayed or not. This accumulation occurs continuously, and because the decomposition process is inhibited due to anaerobic conditions and / or unfavorable environmental conditions so that the development of decomposing microbes is inhibited. Peatlands have a thickness of organic matter of at least $50 \mathrm{~cm}$ and an organic carbon content of at least $18 \%$ [1].

Peat soil have several functions such as a hydrological regulator, biodiversity conservation, world climate guardian, cultivation facilities and fish habitat. However, in broad terms the function of peatland can be grouped into 2, namely the regulatory function and the cultivation function.

Peat soil has the ability to absorb and store water is much higher than land mineral. the ability of peat soils to absorb water is related to the degree of decomposition. Peat with 
fibric, hemic and sapric maturity levels can absorb water by $580-3000 \%, 450-850 \%$ and $<450 \%$, respectively. However, the peat soil will change becomes hydrophobic (repels water) if too dry (irrevesible drying) [6].

Irreversible drying is one of the characteristics of peat soils that occur when the peat, dries with moisture content $<100 \%$ (based on dry weight). Peat material that has undergone irreversible drying has a surface like sand (pseudosand) and becomes poor/does not function as soil due to inherent changes in its organic matter. Peat materials that do not have the ability to hold water will burn easily in the dry season. On the other hand, during the rainy season and on waterlogged land, the peat soil will float, causing the plants above it to move along with the water flow. Therefore, irreversible drying must be controlled so that the peat land can be used in the long term.

One of the approaches in the context of conserving peatlands is to replant with high carbon crops. A planting system that combines trees with food crops is called agroforestry. In this system, tree plants will absorb carbon from the atmosphere and then convert it into biomass which is a source of organic matter. Organic material can also be obtained from food crops grown from this system.high organic matter in the soil will increase the soil's water retention. In addition, trees that have a wide canopy can affect the microclimate, such as low temperatures. Thus evaporation can be reduced and the moisture of the peat soil is maintained. This review aim to explain the role of intercropping system in peatland water conservation

\section{Peatland characteristic}

\subsection{Chemical properties of peat soil}

The chemical properties of peat soil are characteristics that must be considered in peatland management. Peat soils generally have high acidity, namely $\mathrm{pH} 3-4$. The decomposition of peat material in the form of lignin can produce aliphatic and phenolic acids. These phenolic acids can inhibit the development of plant roots and nutrient supply. The nutrient content of peat is strongly influenced by the environmental conditions in which it is formed. The value of the cationic capacity is high because the charge depends on $\mathrm{pH}$. On the other hand, the content of the exchanged bases is very low.

Peat soils have alkaline cations such as $\mathrm{Ca}, \mathrm{Mg}, \mathrm{K}$, and $\mathrm{Na}$ which are very low, especially in thick peat. The thicker the peat, the more alkalis it contains low and the soil reaction becomes increasingly sour (Driessen and Suhardjo, 1976). In on the other hand, the cation exchange capacity (CEC) of peat is classified as high, so that it is saturated base (KB) becomes very low

Peat soils also contain very low micro-trace elements and are tied up strong enough (chelate) by organic matter so that it is not available to plants. Besides the presence of strong reducing conditions causes the micro-elements to be reduced to form which plants cannot absorb. Micro element content in peat soil can be increased by adding mineral soil or adding fertilizer micro.

\subsection{Physical properties of peat soil}

Important physical properties of peat soil related to water conservation are peat maturity, water content, bulk densitythe, bearing capacity), lowering ground level (subsidence), irreversible drying [1]. Peat maturity level is the physical characteristics of peat soil which are the determining factors for the suitability of peat for agricultural development. Soil maturity is also an indicator for some things for example the ability of the soil support the physical load, the amount of depreciation (subsidence) when the soil becomes dry (eg due 
to improved drainage) [8]. Based on the level of maturity, peat is differentiated into sapric (ripe), hemic (half rip), and fibric (raw). The fertility, nutrient availability and soil structure on peatlands more mature peat is relatively better than raw peat.

The height of peat soils in absorbing water is determined by the level of decomposition, porosity and functional groups. Relatively unfinished material decomposed has a high porosity with the proportion of large pores high. Relative total porosity of peat soil high, generally in the $70-95 \%$ range. The total porosity decreases with decomposition and it is very determine the ability of peat to water retain. The higher the porosity, the more water can be absorbed. In addition, the ability of peat soil to absorb water is closely related to the reduction availability of carboxylic and $\mathrm{OH}-$ phenolics.

The peat soil is low bulk density, so that it affects the load-bearing capacity of the plants. The bulk density of peat soil ranged from 0.1 to $0.2 \mathrm{~g} / \mathrm{cc}$. bulk density is influenced by the level of peat maturity, mixture with mineral materials, moisture content, ash content. Soil with high ash content high and more and more mixed with mineral soil and has decomposed, the weight of the volume increases big [9].

Irreversible drying and subsidence have a very significant effect on the quality of the peat soil. Irrevesible drying due to hydrophilic peat changes become hydrophobic so that its ability to absorb water decreases. The reduced ability to absorb water causes the volume of peat shrinking and the peat surface decreases (subsidence). In addition, the cause of subsidence is an increase in the decomposition process due to the release of water from the peat which results in better aeration. Intensive management resulting in compaction is also a contributing factor in subsidence.

\section{Agroforestry system at peatland}

Utilization of peat forest for agricultural land often creates some problems such as decreased soil fertility, increased decomposition of organic matter and the rate of subsidence. One alternative to reduce the risk of using peat forest to become agricultural land is by combining it with tree crops (agroforestry). With an agroforestry system, the risk of failure, erosion, the need for fertilizers or nutrients from outside the garden can be reduced due to recycling of crop residues.

Agroforestry management on peatlands can be done by combining agricultural crops and timber crops. Food crops, vegetables and fruits can become staple crops and their surroundings can be planted with wood (nyamplung, geronggnang, blangiran) and plantation crops (oil palm, rubber). The results expected from this system are foodstuffs, biofuel materials, and energy wood. In adition, the intercropping systems include the use of empty land between staple crops, an increase in the total production of unit area because it is more effective in using light, air and nutrients, while reducing the risk of crop failure and restraint weed growth [10].

Based on the research, agroforestry system on peatland devided to agrisilviculture, silvopasture and agrosilvopastura. The three agroforestry systems are modern pattern. Agrisilviculture (Agrisilvicultural systems) is an agroforestry system is a combination of forestry components (or woody plants) with agricultural components (or non-timber crops). Silvopasture (Silvopastural systems) includes a forestry component (or woody plants) with a livestock component (or livestock/pasture). Agrosilvopasture (Agros ilvopas tural sistems) is the combination of woody (forestry) components with agriculture (seasonal) and simultaneously in the same land management unit [2]. 


\section{Water conservation by agroforestry system}

One of the functions of peatland regulation is as a hydrological buffer. This is because peat is able to store fresh water which can suppress flooding in the rainy season and and releases water in the dry season. The ability to absorb water by peat soils depends on the level of maturity. Peat with fibric, hemic and sapric maturity can absorb water by $450 \%, 450-850 \%$ and $>850 \%$, respectively, of its dry weight or up to $90 \%$ of its volume. However, if the peat soil experiences extreme dryness, it cannot return to normal (irreversible drying). In this condition, the peat soil will float in the rainy season and can be dissolved by the flow of water, unable to absorb water and burn easily in the dry season.

Soil and water management technology is needed in the use of environmentally friendly peatlands. The presence of water in peatlands is greatly influenced by rain and tidal water [6]. Therefore, during the dry season, one way to prevent drought is to suppress evaporation. Evaporation can be reduced by maintaining soil temperature conditions.

The high water content is main physical characteristic of peat. Peat water content are affected by degre of decomposition, types of organic matter, ground water level and management [5] and density of soil [6]. In the intercropping system between rubber and pineapple (IRP), the water content of peat soil was not influenced by soil depth [5]. On the other hand, in the rubber plant monoculture system (TMR), the water content of the peat is lower with increasing soil depth (Fig. 1). Figure 1 also shows that at a depth of $70-90 \mathrm{~cm}$, the water content of the peat soil with the IRP system is higher than that of TMR. IRP sistem create a microclimate that has a good effect and suppresses evaporation which plays an important role in water conservation due to the soil more humid. In addition, litter from plants on it can increase the content of organic matter, thereby increasing the soil's ability to retain water. 

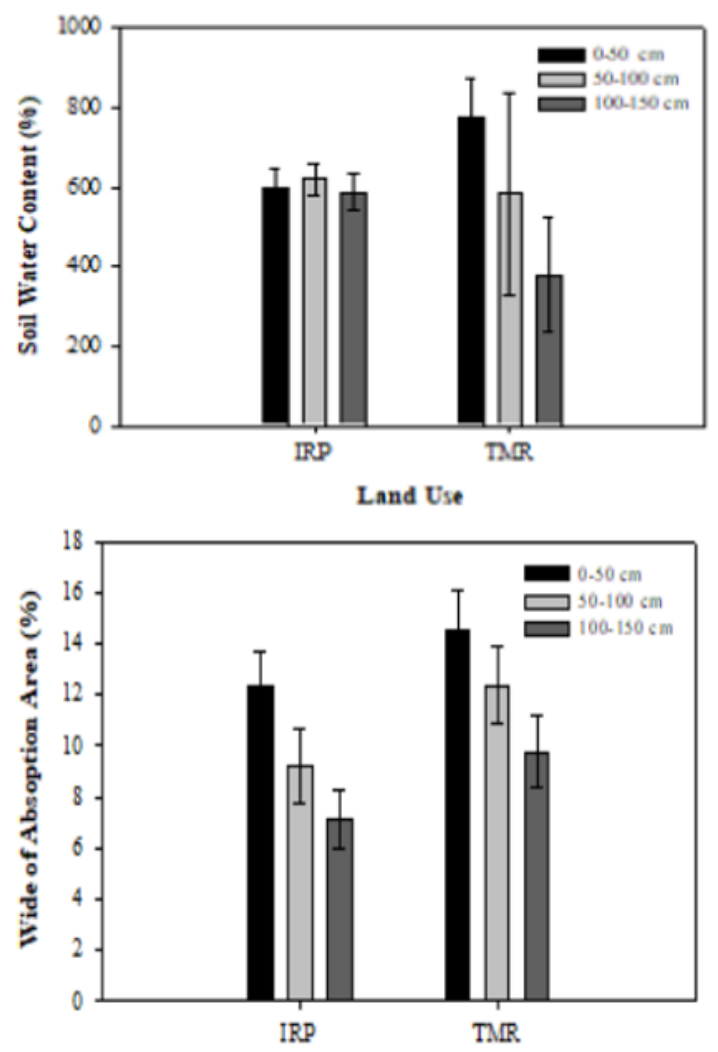

Fig 1. The influence of peatland management on soil water content [5]

Note: $\mathrm{IRP}=$ rubber and pineapple intercrop; $\mathrm{TMR}=$ traditional manage rubber

Peat water content greatly determines the hydrophobicity/hydrophilic in addition to the functional group. The total absorption area of hidrophobical functional group can be used to determine wether peat is hidrophobic. The graphic showed that peat hydrophobicity for IRP (intercroping between rubber and pineapple) and IMR (monocultur rubbe)r deceasing with increasing soil depth. It indicated that peat on surface layer $(0-50 \mathrm{~cm})$ is more vurnerable to drought and fire.

The groud water level measured from the distance from the peat soil surface to the water surface in dug wells in the physiography of peat domes and back swamps varies depending on the type above and the time of measurement (Fig. 2) [3]. Figure 2 shows that the agroforestry system has the lowest air level compared to horticulture shrub in both peat and back swamp physiography. The peat groundwater level also fluctuates according to rainfall so that at the peak of the dry season the ground water level can reach $200 \mathrm{~cm}$ below the soil surface, and conversely at the peak of the rainy season the ground water level can inundate the entire layer of peat soil. High rainfall can causes an increase in water level land surface, while evapotranspiration may cause reduced ground level [4]. 


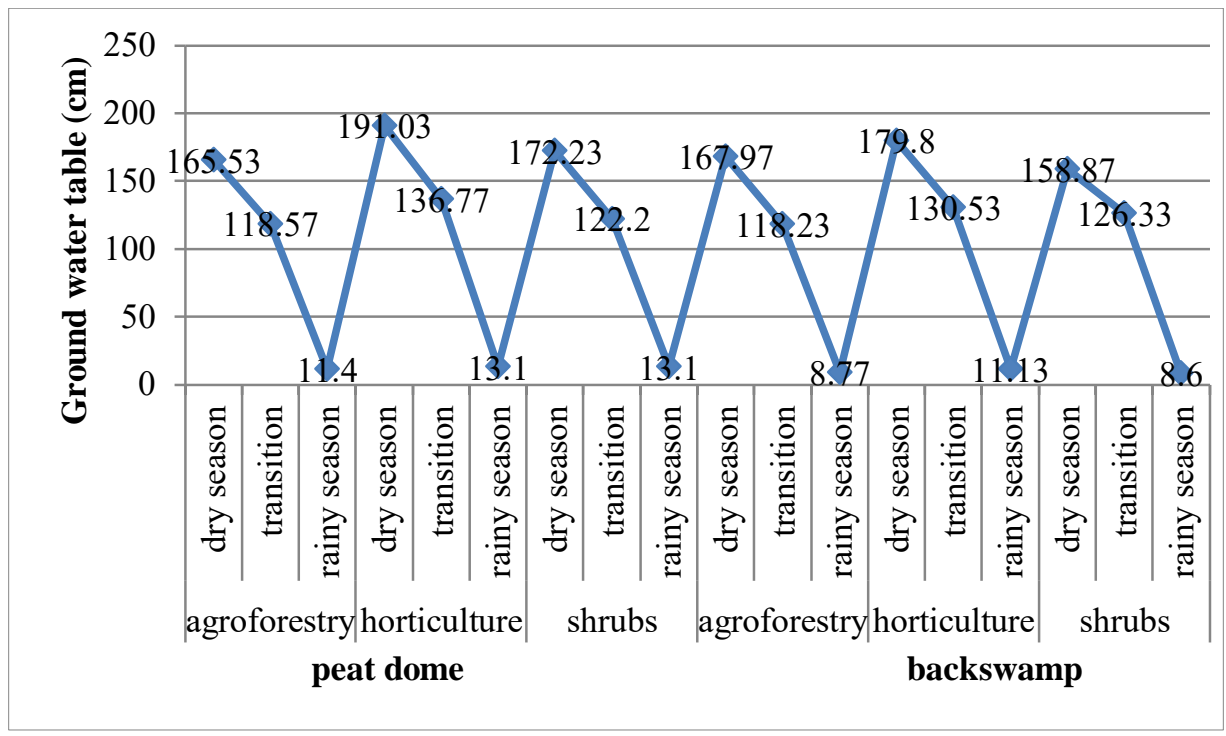

Fig 2. Ground water table dug wells in back swamp and peat dome physiography on dry season, transition and rainy season [3].

\section{Conclusion}

Agroforestry systems can conserve water because the organic matter produced by woody plants produces litter which can maintain the stability of the organic matter. High organic matter can store more water, especially in the dry season. In addition, the microclimate that is created because of the shade from the wood trees can suppress evaporation so that more water can be retained.

\section{References}

1. Agus, F. dan I. G. M. Subiksa. Lahan Gambut: Potensi untuk Pertanian dan Aspek Lingkungan. Balai Penelitian Tanah. Badan Penelitian dan Pengembangan Pertanian. Bogor (2008). [In Bahasa Indonesia].

2. Fahruni. Jurnal Daun. 2,1:12-25(2015). [In Bahasa Indonesia].

3. Harun, M. K., S. Anwar, E. I. K. Putri dan H. S. Arifin. Jurnal Hutan Tropis. 8,3: 315-327(2020). [In Bahasa Indonesia].

4. Giska Hediyanti1, Nurhayati2. Pemodelan Aliran Air Tanah Pada Lahan Gambut. http://download.garuda.ristekdikti.go.id/article.php? (2021). [Accesed on 6 Juli 2021]. [In Bahasa Indonesia].

5. Nurzakiah, S., N. Wakhid and A. Hairani. Journal of Soil Science and Agroclimatology. 17,1:71-77(2020).

6. Immanudin, M. S., J. P. Satria, M. Said and R. Ramadhan. Sriwijaya Journal of Environmental. 4,2:64-77(2019).

7. Lubis, A. Hadi, Syaifina and Lailan. Respon Karakteritik tanah gambut terhadap kebakaran. Scientific Repository. IPB University (2019). [In Bahasa Indonesia]

8. Denah Suswati1 , Bambang Hendro S2, Dja'far Shiddieq2 and Didik Indradewa.. J. Tek. Perkebunan \& PSDL. 1:31-40(2011). [In Bahasa Indonesia]. 
9. Radjagukguk, B. Peat Resource of Indonesia : Its Extent, Characteristics and Development Possibilities. Paper Presented at the Third Seminar on the Geening with Peat Held at Waseda University. Tokyo (1997).

10. Yusriadi Yusriadi, A.M Ikramullah. Jurnal Pendidikan Geosfer. II,2:34-47(2017). [In Bahasa Indonesia]. 